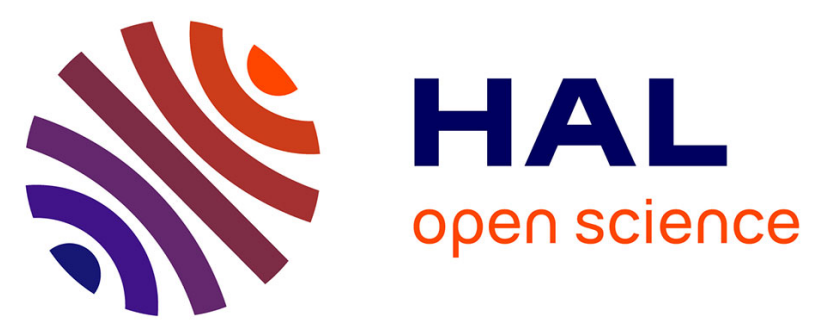

\title{
Human Dental Pulp Fibroblasts Express the "Cold-sensing" Transient Receptor Potential Channels TRPA1 and TRPM8
}

Ikhlas El Karim, Gerard J Linden, Timothy M Curtis, Imad About, Mary K Mcgahon, Christopher R Irwin, Simon A Killough, Fionnuala T Lundy

\section{To cite this version:}

Ikhlas El Karim, Gerard J Linden, Timothy M Curtis, Imad About, Mary K Mcgahon, et al.. Human Dental Pulp Fibroblasts Express the "Cold-sensing" Transient Receptor Potential Channels TRPA1 and TRPM8. Journal of Endodontics, 2011, 37 (4), pp.473-478. 10.1016/j.joen.2010.12.017 . hal03552117

\section{HAL Id: hal-03552117 \\ https://hal.science/hal-03552117}

Submitted on 2 Feb 2022

HAL is a multi-disciplinary open access archive for the deposit and dissemination of scientific research documents, whether they are published or not. The documents may come from teaching and research institutions in France or abroad, or from public or private research centers.
L'archive ouverte pluridisciplinaire HAL, est destinée au dépôt et à la diffusion de documents scientifiques de niveau recherche, publiés ou non, émanant des établissements d'enseignement et de recherche français ou étrangers, des laboratoires publics ou privés. 


\title{
Human Dental Pulp Fibroblasts Express the "Cold-sensing" Transient Receptor Potential Channels TRPA1 and TRPM8
}

\author{
Ikblas A. El Karim, BDS, PbD, * Gerard J. Linden, BSc, BDS, PhD, * Timothy M. Curtis, BSc, PbD, * \\ Imad About, MS, PhD, ${ }^{\dagger}$ Mary K. McGabon, BSc, PbD, * Christopher R. Irwin, BSc, BDS, PbD, * \\ Simon A. Killough, BSc, BDS, PbD, * and Fionnuala T. Lundy, BSc, PbD*
}

\section{Ahstract}

Introduction: Transient receptor potential (TRP) channels comprise a group of nonselective calcium-permeable cationic channels, which are polymodal sensors of environmental stimuli such as thermal changes and chemicals. TRPM8 and TRPA 1 are cold-sensing TRP channels activated by moderate cooling and noxious cold temperatures, respectively. Both receptors have been identified in trigeminal ganglion neurones, and their expression in nonneuronal cells is now the focus of much interest. The aim of this study was to investigate the molecular and functional expression of TRPA1 and TRPM8 in dental pulp fibroblasts. Methods: Human dental pulp fibroblasts were derived from healthy molar teeth. Gene and protein expression was determined by polymerase chain reaction and Western blotting. Cellular localization was investigated by immunohistochemistry, and TRP functionality was determined by $\mathrm{Ca}^{2+}$ microfluorimetry. Results: Polymerase chain reaction and Western blotting showed gene and protein expression of both TRPA1 and TRPM8 in fibroblast cells in culture. Immunohistochemistry studies showed that TRPA1 and TRPM8 immunoreactivity co-localized with the human fibroblast surface protein. In $\mathrm{Ca}^{2+}$ microfluorimetry studies designed to determine the functionality of TRPA1 and TRPM8 in pulp fibroblasts, we showed increased intracellular calcium $\left(\left[\mathrm{Ca}^{2+}\right]_{\mathrm{i}}\right)$ in response to the TRPM8 agonist menthol, the TRPA1 agonist cinnamaldehyde, and to cool and noxious cold stimuli, respectively. The responses to agonists and thermal stimuli were blocked in the presence of specific TRPA1 and TRPM8 antagonists. Conclusions: Human dental pulp fibroblasts express TRPA1 and TRPM8 at the molecular, protein, and functional levels, indicating a possible role for fibroblasts in mediating cold responses in human teeth. (J Endod 2011;37:473-478)

\section{Key Words}

Dental pulp, fibroblasts, human, transient receptor potential

The he cellular and molecular mechanisms underlying thermal transduction in mammals is being gradually unfolded by recent research on the transient receptor potential (TRP) family of ion channels. TRP channels comprise a group of nonselective calcium permeable cationic channels that respond to environmental stimuli such as thermal changes by activation of calcium fluxes. The TRP family contains nearly 30 members distributed into six subfamilies according to their sequence and function. The transient receptor potential melastatin-8 (TRPM8) and transient receptor potential ankyrin-1 (TRPA1) channels are expressed in subpopulations of sensory neurones and have been proposed to mediate innocuous and noxious cold sensations, respectively (1-3). TRPA1 is coexpressed in a subpopulation of somatosensory neurones expressing the heat-sensitive transient receptor potential vanilloid-1 (TRPV1), whereas TRPM8 is expressed in the small dorsal root ganglia neurones and in neurones from the trigeminal ganglion $(1,4)$. In addition to their neuronal expression, these channels have also been shown on nonneuronal cells including keratinocytes (5), epithelial cells (6), and synoviocytes (7) where their activation has been proposed to coordinate neural responses. We recently identified TRP channel expression in human odontoblasts (8) and hypothesize that pulp fibroblasts also express TRP channels because these cells modulate pulpal homeostasis $(9,10)$ and comprise the major cell type in the dental pulp. Therefore, the aims of this study were to investigate the molecular expression and localization of TRPA1 and TRPM8 in human dental pulp fibroblasts and show their functionality using chemical agonists and cold stimuli.

\section{Cell Gulture}

\section{Materials and Methods}

Human dental pulp fibroblasts were derived from extracted healthy third molar teeth obtained from patients aged 19 to 30 years old and collected with consent under the approval of the Office for Research Ethics Committees Northern Ireland. Immediately after extraction, the teeth were sectioned to remove the pulp and processed for explant culture as previously described (11). Cells derived from dental pulp explants were cultured in minimal essential medium with L-glutamine supplemented with $10 \%$ fetal bovine serum, $100 \mathrm{UI} / \mathrm{mL}$ penicillin, and $100 \mu \mathrm{g} / \mathrm{mL}$ streptomycin. Cells between passages 4 and 6 were used in all experiments.

\section{RNA Extraction, Complementary DNA Synthesis, and Reverse-transcriptase Polymerase Chain Reaction}

Total RNA from cells grown to $70 \%$ confluence in T75 flasks in culture was prepared using the RNeasy MiniKit (Qiagen, Crawley, UK) according to the protocol provided by the manufacturer. Complementary DNA was synthesized from $1 \mu \mathrm{g}$ of extracted RNA with the Superscript First Strand Synthesis System (Invitrogen, Paisley, UK) and an oligo-dT primer mix according to the manufacturer's guidelines. Conventional reverse-transcriptase polymerase chain reaction (PCR) using primers specific to human TRPA1, (5'-TGGTGCACAAATAGACCCAGT- $3^{\prime}, 3^{\prime}$-TGGGCACCTTTAGAGAGTAGC- $5^{\prime}$ ) and TRPM8 (5'-GATTTTCACCAATGACCGCCG-3' $3^{\prime}, 3^{\prime}$-CCCCAGCAGCATTGATGTCG- $5^{\prime}$ ) were used. PCR reactions were 


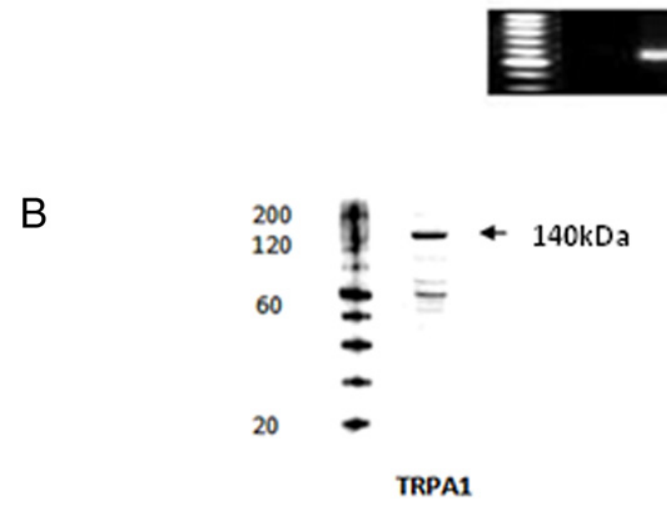

503bp TRPM8
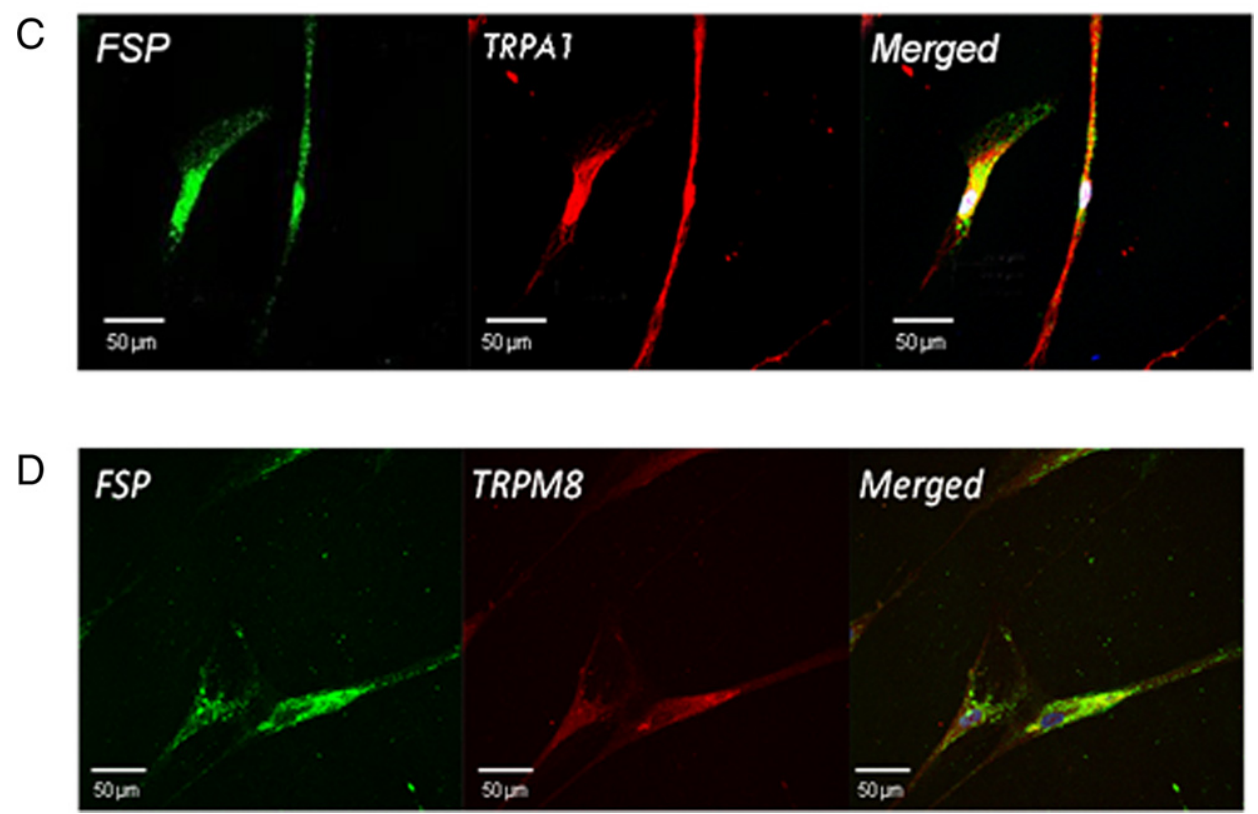

Figure 1. Molecular and protein expression of TRPA1 and TRPM8 in cultured human pulp fibroblasts using PCR, western blotting and immunohistochemistry. (A) Two percent agarose gel electrophoresis showing PCR amplification products for TRPA1 and TRPM8 at the predicted sizes. (B) Western blots for TRPA1 and TRPM8 showing immunoreactive bands at the predicted molecular masses of $140 \mathrm{kDa}$ and $125 \mathrm{kDa}$, respectively. $(C$ and $D$ ) Confocal photomicrographs showing cellular localization of TRPA1 and TRPM8 in cultured human pulp fibroblasts. Fibroblast cells were positively identified by staining with FSP (green). These cells also stained positively for TRPA1/TRPM8 (red), and colocalization was evident when the images were merged (yellow). Cells were counterstained with $4^{\prime}, 6$ diamidino-2phenylindole for nuclear enhancement (blue).

performed using Platinum Taq DNA polymerase (Invitrogen) with the following parameters: denaturation at $94^{\circ} \mathrm{C}$ for 30 seconds, annealing at $56^{\circ} \mathrm{C}$ for 45 seconds, and extension at $72^{\circ} \mathrm{C}$ for 90 seconds. A total of 33 cycles was performed, followed by a final extension at $72^{\circ} \mathrm{C}$ for 10 minutes. PCR products were analyzed by electrophoresis in $2 \%$ agarose gel and visualized by ethidium bromide staining. Parallel reactions were run for each RNA sample in the absence of reverse transcriptase to confirm the absence of genomic DNA contamination.

\section{Western Blotting}

Cultured cells were lysed for 30 minutes on ice with $10 \mathrm{mmol} / \mathrm{L}$ Tris-HCL buffer $(\mathrm{pH}=7.4)$ containing $1 \%$ sodium dodecyl sulfate (SDS) and "complete" protease inhibitors cocktail (Roche, Hertfordshire, UK). The total protein was determined using the bicinchoninic acid protein assay, and equal amounts of protein $(27 \mu \mathrm{g})$ were fractioned by SDS-polyacrylamide gel electrophoresis and blotted onto nitrocellulose. The blots were blocked in 5\% nonfat milk for 1 hour before probing with rabbit polyclonal primary antibody to TRPA1 (1:500) or TRPM8 (1:500) (Abcam, Cambridge, UK). Detection of the bound primary antibody was achieved using appropriate antispecies antibody conjugates (Dako, Glostrup, Denmark) and chemiluminescent substrates. Western blotting and PCR images were visualized using a G:Box chemiluminescent imaging system (Syngene, Cambridge, UK).

\section{Immunohistochemistry}

For double-staining fluorescence immunohistochemistry, cells were grown on cover slips, acetone fixed, and processed for indirect immunohistochemistry using primary rabbit polyclonal antibodies 
A

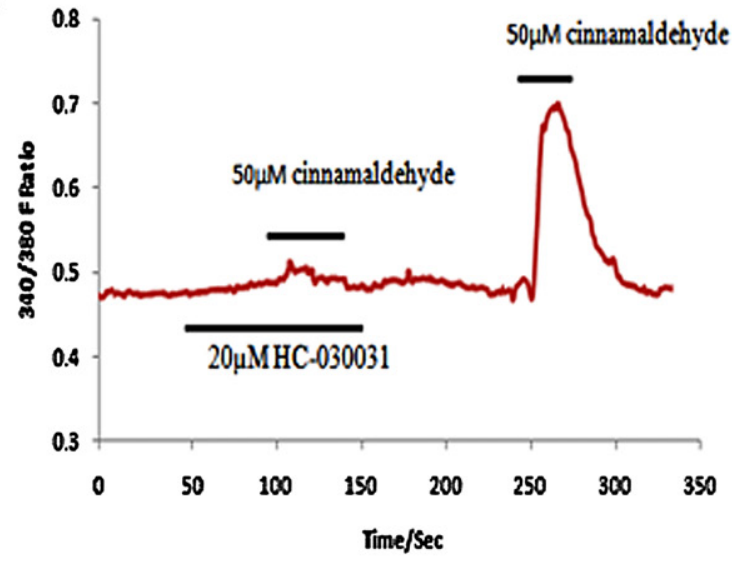

C

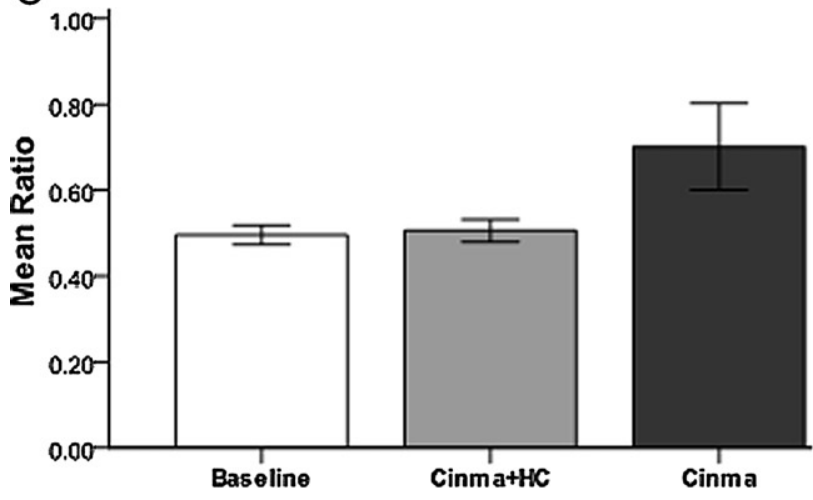

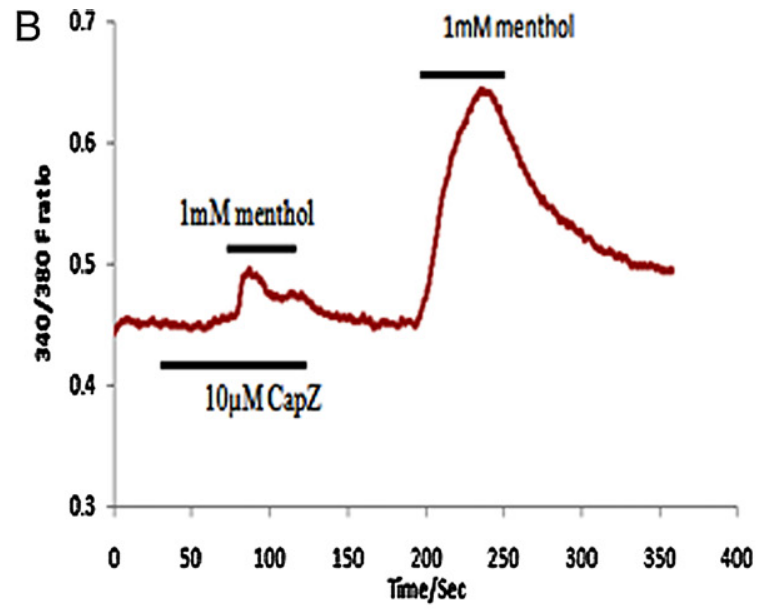

D

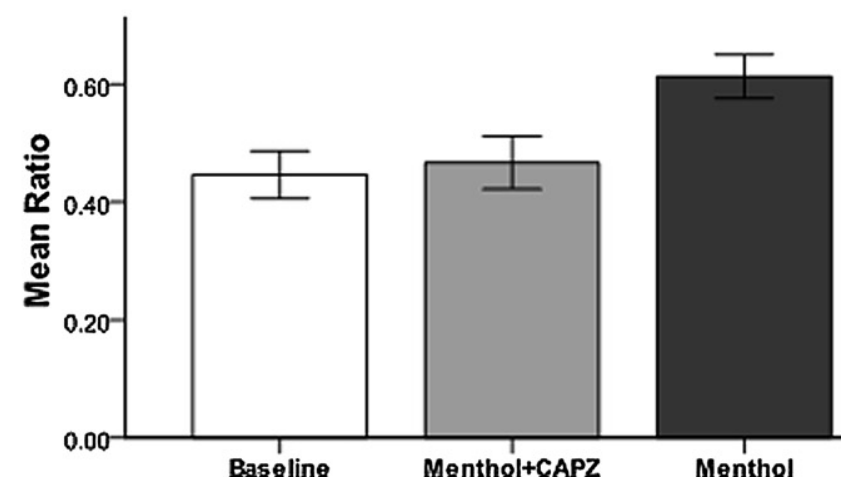

Figure 2. Pharmacological activation of TRPA1 and TRPM8 in human pulp fibroblasts. Representative traces of $\left(\mathrm{Ca}^{2+}\right)_{\mathrm{i}}$ in response to agonists and antagonists. (A) An increase in $\left(\mathrm{Ca}^{2+}\right)_{\mathrm{i}}$, in cultured fibroblasts in response to $50 \mu \mathrm{mol} / \mathrm{L}$ cinnamaldehyde, which was blocked in the presence of the TRPA1 antagonist HC$030031(P<.001)$. $(B)$ The response of fibroblasts to $1 \mathrm{mmol} / \mathrm{L}$ menthol was attenuated by the TRPM8 antagonist capsazepine $(P<.001)$. $(C$ and $D)$ Bar graph summaries of cell responses to agonists and antagonists. Error bars indicate the standard error of the mean.

against human TRPA1 (Abcam) or TRPM8 (Alomone Labs, Jerusalem) and mouse monoclonal antihuman fibroblast surface protein (FSP) antibody (Abcam). Appropriate antispecies Alex Fluor 488 and Alexa Fluor 594 secondary antibody conjugates (Invitrogen) were used for secondary detection. Briefly, specimens were incubated with anti-TRPA1 or anti-TRPM8 antibodies diluted 1:100 overnight at room temperature and then washed extensively with PBS before incubation overnight with anti-FSP (1:500). Secondary antibodies (1:500) were applied for 45 minutes at $37^{\circ} \mathrm{C}$ and the tissue sections washed again. Cover slips were mounted in VectaShield with $4^{\prime}, 6$ diamidino-2-phenylindole (Vector Labs, Peterborough, UK) to counterstain the nuclei. Images were obtained using a Leica TCS SP5 confocal microscope (Milton Keynes, UK). Control sections incubated in the absence primary were negative.

\section{$\mathrm{Ca}^{2+}$ Microfluorimetry}

Intracellular calcium $\left(\left[\mathrm{Ca}^{2+}\right]_{\mathrm{i}}\right)$ was estimated fluorometrically in cultured pulp fibroblasts loaded with the intracellular $\mathrm{Ca}^{2+}$ probe fura-2AM (Enzo Life Sciences, Exeter, UK). Cells were grown on glass coverslips overnight in minimal essential medium supplemented with $10 \% \mathrm{FBS}, 100 \mathrm{UI} / \mathrm{mL}$ penicillin, and $100 \mu \mathrm{g} / \mathrm{mL}$ streptomycin before incubation in the dark with fura-2AM $(5 \mu \mathrm{mol} / \mathrm{L})$ for 1 hour at $37^{\circ} \mathrm{C}$. Coverslips bearing the adherent cells were then placed in a recording chamber mounted on the stage of an inverted microscope (Nikon Eclipse TE2000, Surrey, UK) and superfused with
Hank's solution $(140 \mathrm{mmol} / \mathrm{L} \mathrm{NaCl}, 5 \mathrm{mmol} / \mathrm{L} \mathrm{KCl}, 5 \mathrm{mmol} / \mathrm{L} \mathrm{D}$ glucose, $1.3 \mathrm{mmol} / \mathrm{L} \mathrm{MgCl}_{2}, 2 \mathrm{mmol} / \mathrm{L} \mathrm{CaCl}$, and $10 \mathrm{mmol} / \mathrm{L}$ 4-[2-hydroxyethyl]-1-piperazineethanesulfonic acid [HEPES]; $\mathrm{pH}=$ 7.4) at $37^{\circ} \mathrm{C}$. The temperature of the chamber was controlled with an inbuilt Peltier device (PTC-10; ALA Scientific, Westbury, $\mathrm{NY})$. Alternating excitation wavelengths of 340 and $380 \mathrm{~nm}$ light were delivered from a dual monochromator (5-nm bandwidth) using a light chopper (Cairn Research Ltd, Faversham, UK). Emitted fluorescence was measured from the side port of the microscope via an adjustable rectangular window, a filter $(510 \mathrm{~nm})$, and a photon counting photomultiplier tube in the light path. Fluorescence equipment was controlled by Acquisition Engine (Cairn) software (V1.1.5), which was also used for analysis of the fluorescence data. At the end of each experiment, background fluorescence was quantified by incubation of the cells with $5 \mathrm{mmol} / \mathrm{L} \mathrm{Mn}^{2+}$ in $\mathrm{Ca}^{2+}$ free solution. Changes in the ratio of the background-corrected fluorescence emitted at each excitation wavelength $(R=F 340 / F 380)$ was used as a measure of changes in the cytoplasmic $\mathrm{Ca}^{2+}$ concentration (12). A positive $\mathrm{Ca}^{2+}$ response was defined as a change in the $\mathrm{F} 340$ / F380 ratio greater than 4 standard deviations above the background noise.

Cells were stimulated with the TRPM8 agonist menthol (Sigma, Poole, UK) or TRPA1 agonist cinnamaldehyde (Sigma). Thermal stimuli were induced by decreasing the temperature in the recording chamber at a rate of $0.13^{\circ} \mathrm{C} / \mathrm{s}$ with an inbuilt Peltier device (PTC10). The selective TRPA1 antagonist HC-030031 (Tocris, Bristol, 

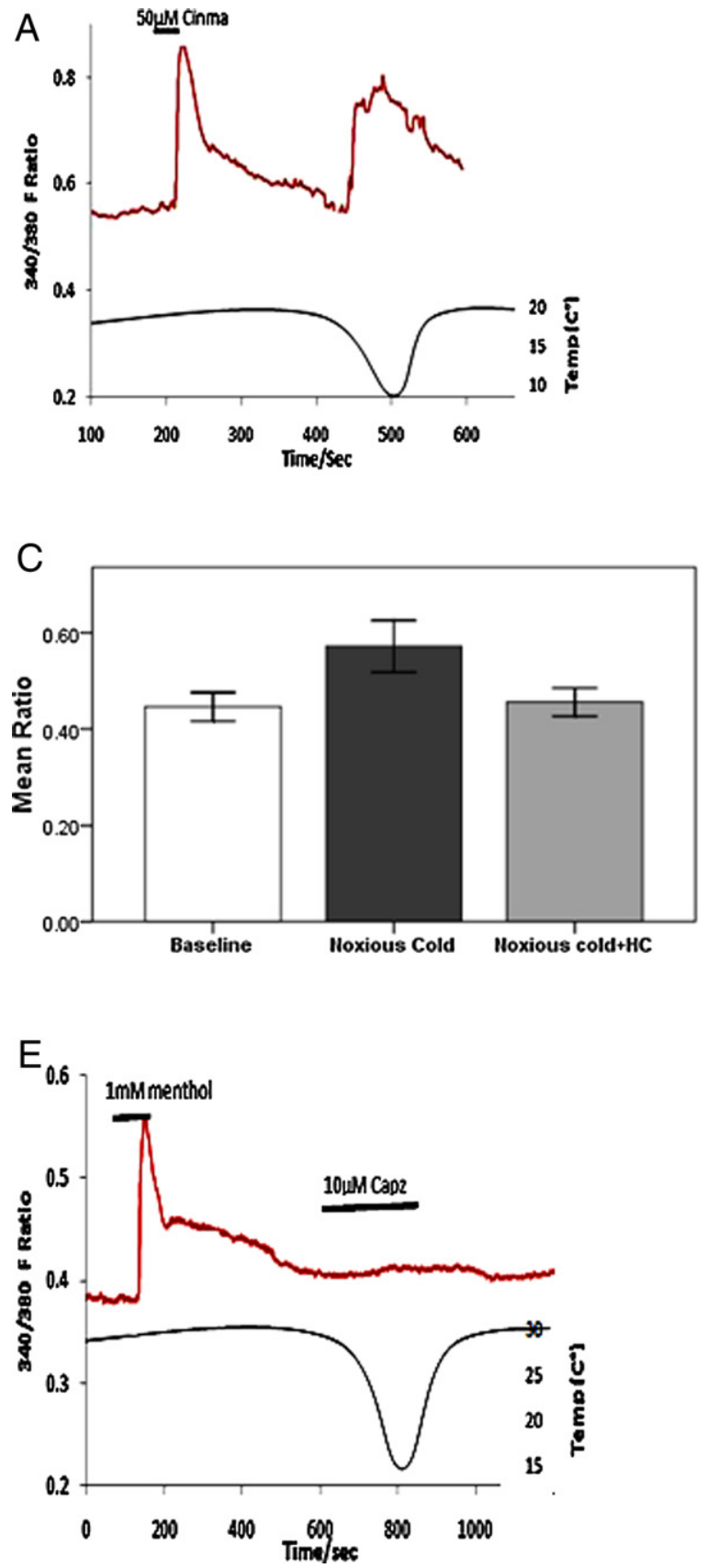
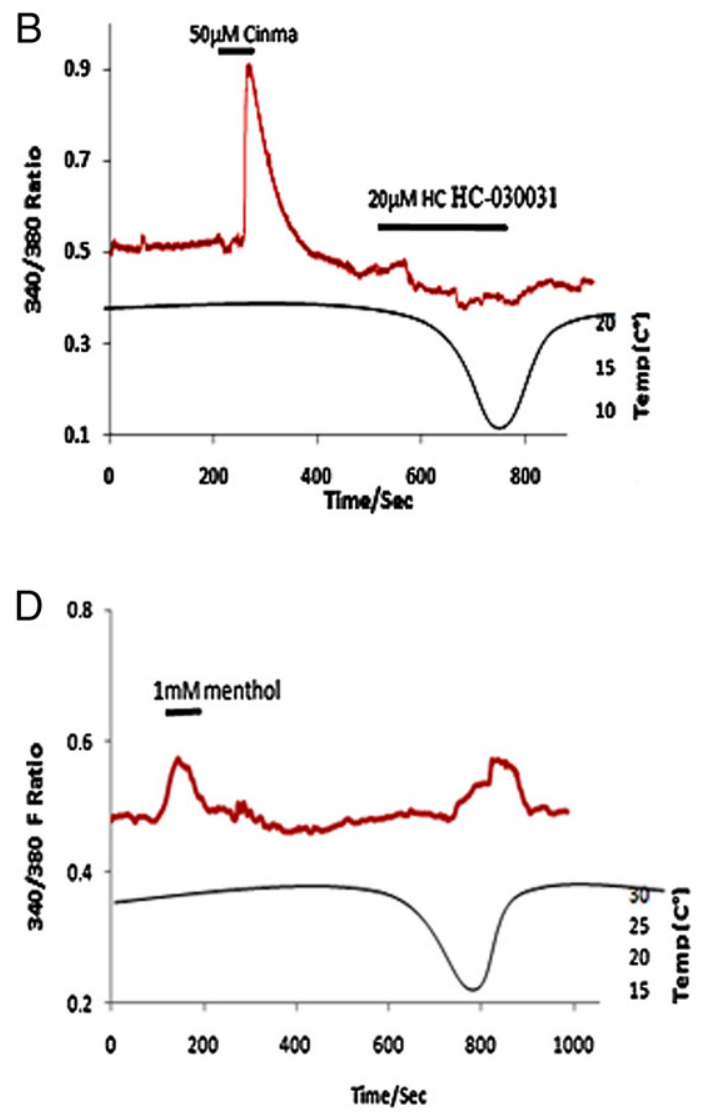

$\mathrm{F}$

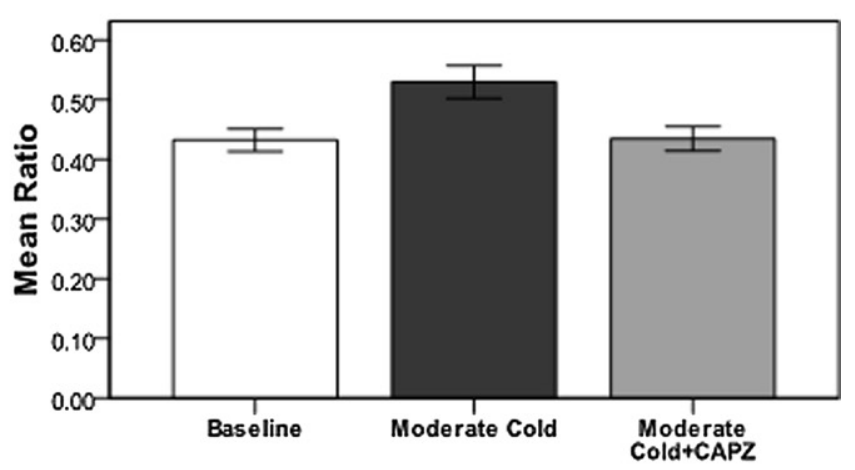

Figure 3. Human pulp fibroblasts' response to thermal stimuli. Simultaneous recording of $\left(\mathrm{Ca}^{2+}\right)_{\mathrm{i}}$ (top trace) and bath temperature (bottom trace) during the application of thermal stimuli $(A-F)$ to cultured pulp fibroblasts. $(A)$ Cinnamaldehyde-responsive cell showing the response to noxious cold (threshold $12^{\circ} \pm 2^{\circ} \mathrm{C}$ ) $(P<.001) .(B)$ The response to noxious cold was abolished in the presence of the TRPA1 antagonist HC-030031 $(P<.001)$. $(C)$ The summary of the fibroblast response to noxious cold in the presence and absence of antagonists. $(D)$ The menthol-responsive cell showing the response to innocuous cold (threshold $22^{\circ} \pm$ $\left.3^{\circ} \mathrm{C}\right)(P<.001)$. $(E)$ The response to innocuous cold was abolished in the presence of the TRPM8 antagonist capsazepine $(P<.001)$. $(F)$ Bar graph summaries of cell responses to moderate cold. Error bars indicate the standard error of the mean.

UK) and the TRPM8 antagonist capsazepine (7) (Sigma) were used to attenuate the corresponding agonist- and thermal-induced responses.

\section{Data Analysis}

Data are presented as means \pm standard error of the mean. For statistical analysis, paired and one-sample Student $t$ tests were used with $P \leq .05$ considered statistically significant.

\section{Results}

\section{Molecular Identification of TRPA1 and TRPM8 in Pulp Fibroblasts}

Gene and protein expression of TRPA1 and TRPM8 was shown by PCR and Western blotting at the predicted sizes and molecular masses, respectively (Fig. $1 A$ and $B$ ). Double-staining immunohistochemistry revealed the cellular localization of TRPA1 (Fig. 1C) and TRPM8 (Fig. $1 D$ ) and established the colocalization of TRP channel expression 
with the fibroblast marker FSP, confirming the fibroblast phenotype of the cells.

\section{Functional Expression of TRPA1 and TRPM8 in Pulp Fibroblasts}

The functional expression of TRPA1 and TRPM8 was investigated by $\mathrm{Ca}^{2+}$ microfluorimetry using chemical ligands and cold stimuli (Figs. 2 and 3). Exposure of cells to $50 \mu \mathrm{mol} / \mathrm{L}$ cinnmaldehye produced a significant increase in $\left(\mathrm{Ca}^{2+}\right)_{\mathrm{i}}$ that was substantially reduced in the presence of the TRPA1 antagonist HC-030031 (Fig. $2 A ; P<.001$, $\mathrm{n}=12)$. The TRPM 8 agonist menthol $(1 \mathrm{mmol} / \mathrm{L})$ also induced a significant increase in $\left(\mathrm{Ca}^{2+}\right)_{i}$, which was attenuated in the presence of the TRPM8 antagonist capsazepine (Fig. $2 B, P<.001, \mathrm{n}=7$ ).

In addition to treatment with chemical agonists, TRPA1 and TRPM8 were also activated by thermal stimuli. The exposure of cells to noxious cold by reducing the bath temperature to $12^{\circ} \pm 2^{\circ} \mathrm{C}$ resulted in a significant increase in $\left(\mathrm{Ca}^{2+}\right)_{\mathrm{i}}$ in cinnamaldehyde-responsive cells (Fig. $3 A, P<.001, \mathrm{n}=11$ ). The cellular response to cold was abolished in the presence of the TRPA1 antagonist HC-030031 (Fig. 3B, $P<.001$ ), suggesting specific mediation of the noxious cold response via TRPA1. Similarly, introducing moderate cold in the range of $22^{\circ} \pm 3^{\circ} \mathrm{C}$ resulted in an increase in $\left(\mathrm{Ca}^{2+}\right)_{\mathrm{i}}$ in menthol-sensitive cells (Fig. $3 D, P<.001$, $\mathrm{n}=9$ ), which was abolished in the presence of TRPM8 antagonist, suggesting a specific TRPM8 response (Fig. $3 E, P<.001$ ).

\section{Discussion}

The present report shows for the first time that human dental pulp fibroblasts express the thermosensitive TRP channels TRPA1 and TRPM8. The gene and protein expression of these channels was shown with PCR and Western blotting in concurrence with previous reports of TRP expression in nonneuronal cells $(5,7,13)$. The dental pulp is populated by different cell types, and pulp cell cultures may be heterogeneous. However, the cell culture method we used in this work has been used previously by our research group to derive pulp fibroblasts from dental pulp explants (11). In the current study, we cannot exclude the possible contamination by other cells during PCR, Western blot, and functional assays; however, our immunohistochemical colocalization of TRPA1 and TRPM8 with human fibroblast surface protein confirms that at least part of these responses are indeed of pulp fibroblasts. This finding provides a novel role for pulp fibroblasts in sensing environmental stimuli via the activation of TRP channels as reported for other nonneuronal cells like skin keratinocytes (5) and epithelial cells (13)

The physiological significance of thermal sensation by nonneuronal cells is gradually emerging, and it has been suggested that the activation of thermo-TRP channels in nonneuronal cells could lead to the release of diffusible factors that could affect the function of sensory neurones $(14,15)$. In this regard, TRPV3 in keratinocytes has been shown to transmit temperature information to neurones via adenosine triphosphate and prostaglandin $\mathrm{E}_{2}$ release to influence both acute nociception and hyperalgesia $(14,15)$. However, whether TRPA1 or TRPM8 could similarly transmit cold temperature sensation to sensory neurones remains to be investigated.

In addition to their roles as sensors of environmental stimuli, TRP channel activation has also been associated with the development of neurogenic inflammation. It is known that TRPA1 is a polymodal channel, which is activated not only by cold but also by a variety of chemical irritants including peroxides $(16,17)$, cigarette smoke (18), and pungent compounds $(2,19,20)$. After activation, TRP channel expression by dental pulp neurones could have important roles in transducing thermal stimuli into the sensation of pain (21).
In addition to eliciting pain, it has also been proposed that the activation of TRP channels on sensory neurones in the airways could evoke protective responses by local release of neuropeptides from the peripheral sensory nerve terminals or by sympathetically or vagally mediated neuronal reflexes (18). However, peripheral nerve terminals are not unique sources of neuropeptides, and it has recently been shown that TRPA1 and TRPM8 mediate inflammation via the release of neuropeptides and inflammatory cytokines from nonneuronal cells $(13,18)$. In the context of the dental pulp, it is known that neuropeptides regulate the expression of angiogenic growth factors in human dental pulp fibroblasts (22). Furthermore, in addition to their well-defined roles in repair and remodelling orchestrated by cytokines, growth factors, and extracellular matrix molecules, pulp fibroblasts also synthesize some neuropeptides and their receptors $(11,23)$. It is reasonable to speculate that the activation of TRPA1 in dental pulp fibroblasts may modulate pulpal inflammation through the release or recognition of neuropeptides and the subsequent development of the neurogenic inflammatory response. TRPA1 chemical agonists such as peroxides (24) or cold stimuli (25) can penetrate enamel and dentine to reach the dental pulp. Peroxides used in bleaching products are known to cause bleaching sensitivity and pain (26). Bleaching has been shown to increase pulpal expression of substance P (27), and it is possible that TRPA1 activation may have a role in modulating this response. Additional physiological roles for TRPA1 channel activation could involve cell proliferation/differentiation as has previously been described for skin keratinocytes (5).

\section{Conclusions}

Our findings show the functional expression of TRPA1 and TRPM8 in dental pulp fibroblasts, which may have major physiological importance for pulpal homeostasis.

\section{Acknowledgments}

The authors gratefully acknowledge Catherine Fulton and the staff in the Tissue Core Facility, QUB, for technical assistance and Professor Alex Zholos, QUB, for providing TRPM8 antibody.

The authors deny any conflicts of interest related to this study.

\section{References}

1. Peier AM, Moqrich A, Hergarden AC, et al. A TRP channel that senses cold stimuli and menthol. Cell 2002;108:705-15.

2. Story GM, Peier AM, Reeve AJ, et al. ANKTM1, a TRP-like channel expressed in nociceptive neurons, is activated by cold temperatures. Cell 2003;112:819-29.

3. Karashima Y, Talavera K, Everaerts W, et al. TRPA1 acts as a cold sensor in vitro and in vivo. Proc Natl Acad Sci U S A 2009;106:1273-8.

4. McKemy DD, Neuhausser WM, Julius D. Identification of a cold receptor reveals a general role for TRP channels in thermosensation. Nature 2002;416:52-8.

5. Atoyan R, Shander D, Botchkareva NV. Non-neuronal expression of transient receptor potential type A1 (TRPA1) in human skin. J Invest Dermatol 2009;129: 2312-5.

6. Bidaux G, Roudbaraki M, Merle C, et al. Evidence for specific TRPM8 expression in human prostate secretory epithelial cells: Functional androgen receptor requirement. Endocr Relat Cancer 2005;12:367-82.

7. Kochukov MY, McNearney TA, Fu Y, et al. Thermosensitive TRP ion channels mediate cytosolic calcium response in human synoviocytes. Am J Physiol Cell Physiol 2006;291:C424-32.

8. El Karim IA, Linden GJ, Curtis TM, et al. Human odontoblasts express functional thermo-sensitive TRP channels: implications for dentine sensitivity. Pain 2010 Dec 16 [Epub ahead of print].

9. Coil J, Tam E, Waterfield JD. Proinflammatory cytokine profiles in pulp fibroblasts stimulated with lipopolysaccharide and methyl mercaptan. J Endod 2004;30:88-91.

10. Wisithphrom K, Murray PE, Windsor L. Interleukin-1 $\alpha$ alters the expression of matrix metalloproteinases and collagen degradation by pulp fibroblasts. J Endod 2006;32:186-92. 
11. Killough SA, Lundy FT, Irwin CR. Substance P expression by human dental pulp fibroblasts: A potential role in neurogenic inflammation. J Endod 2009;35: 73-7.

12. Grynkiewicz G, Poenie M, Tsien RY. A new generation of $\mathrm{Ca}^{2+}$ indicators with greatly improved fluorescence properties. J Biol Chem 1985;260:3440-50.

13. Sabnis AS, Reilly CA, Veranth JM, et al. Increased transcription of cytokine genes in human lung epithelial cells through activation of a TRPM8 variant by cold temperatures. Am J Physiol Lung Cell Mol Physiol 2008;295:L194-200.

14. Mandadi S, Sokabe T, Shibasaki K, et al. TRPV3 in keratinocytes transmits temperature information to sensory neurons via ATP. Pflugers Arch 2009;458:1093-102.

15. Huang SM, Lee $\mathrm{H}$, Chung MK, et al. Overexpressed transient receptor potential vanilloid 3 ion channels in skin keratinocytes modulate pain sensitivity via prostaglandin E2. J Neurosci 2008;28:13727-37.

16. Andersson DA, Gentry C, Moss S, et al. Transient receptor potential A1 is a sensory receptor for multiple products of oxidative stress. J Neurosci 2008; 28:2485-94.

17. Sawada $Y$, Hosokawa $H$, Matsumura K, et al. Activation of transient receptor potential ankyrin 1 by hydrogen peroxide. Eur J Neurosci 2008;27:1131-42.

18. Andre E, Campi B, Materazzi S, et al. Cigarette smoke-induced neurogenic inflammation is mediated by alpha, beta-unsaturated aldehydes and the TRPA1 receptor in rodents. J Clin Invest 2008;118:2574-82.
19. Bandell M, Story GM, Hwang SW, et al. Noxious cold ion channel TRPA1 is activated by pungent compounds and bradykinin. Neuron 2004;41:849-57.

20. Bautista DM, Jordt SE, Nikai T, et al. TRPA1 mediates the inflammatory actions of environmental irritants and proalgesic agents. Cell 2006;124: 1269-82.

21. Park CK, Kim MS, Fang Z, et al. Functional expression of thermo-transient receptor potential channels in dental primary afferent neurons: Implication for tooth pain. J Biol Chem 2006;281:17304-11.

22. El Karim IA, Linden GJ, Irwin CR, Lundy FT. Neuropeptides regulate expression of angiogenic growth factors in human dental pulp fibroblasts. J Endod 2009;35:829-33.

23. Killough SA, Lundy FT, Irwin CR. Dental pulp fibroblasts express neuropeptide Y Y1 receptor but not neuropeptide Y. Int Endod J 2010;43:835-42.

24. Hanks CT, Fat JC, Wataha JC, et al. Cytotoxicity and dentin permeability of carbamide peroxide and hydrogen peroxide vital bleaching materials, in vitro. J Dent Res 1993;72:931-8.

25. Jorgensen MG, Carroll WB. Incidence of tooth sensitivity after home whitening treatment. J Am Dent Assoc 2002;133:1076-82.

26. Trowbridge HO, Franks M, Korostoff E, et al. Sensory response to thermal stimulation in human teeth. J Endod 1980;6:405-12.

27. Caviedes-Bucheli J, Ariza-Garcia G, Restrepo-Mendez S, et al. The effect of tooth bleaching on substance P expression in human dental pulp. J Endod 2008;34:1462-5. 